\title{
Alcanivorax dieselolei, an alkane-degrading bacterium associated with the mucus of the zoanthid Palythoa caribaeorum (Cnidaria, Anthozoa)
}

\author{
Campos, FF. ${ }^{a *}$, Garcia, JE. ${ }^{a}$, Luna-Finkler, CL. ${ }^{a}$, Davolos, CC. ${ }^{b}$ Lemos, MVF. ${ }^{b}$ and Pérez, CD. ${ }^{a}$ \\ ${ }^{a}$ Grupo de Pesquisa em Antozoários, Programa de Pós-Graduação em Saúde Humana e Meio Ambiente, \\ Centro Acadêmico de Vitória, Universidade Federal de Pernambuco - UFPE, Rua Alto do Reservatório, s/n, \\ CEP 55608-680, Bela Vista, Vitória de Santo Antão, PE, Brazil \\ bLaboratório de Genética de Bactérias, Departamento de Biologia Aplicada, Universidade Estadual Paulista "Júlio de \\ Mesquita Filho" - UNESP, Via de Acesso Prof. Paulo Donato Castellane, s/n, CEP 14884-900, Jaboticabal, SP, Brazil \\ *e-mail: felipecampospb@gmail.com
}

Received: September 13, 2013 - Accepted: January 20, 2014 - Distributed: May 31, 2015

(With 2 Figures)

\begin{abstract}
Analyses of $16 \mathrm{~S}$ rDNA genes were used to identify the microbiota isolated from the mucus of the zoanthid Palythoa caribaeorum at Porto de Galinhas on the coast of Pernambuco State, Brazil. This study is important as the first report of this association, because of the potential biotechnological applications of the bacterium Alcanivorax dieselolei, and as evidence for the presence of a hydrocarbon degrading bacterium in a reef ecosystem such as Porto de Galinhas.
\end{abstract}

Keywords: 16S rDNA, microbiota, biodegradation, hydrocarbons, cnidarians.

\section{Alcanivorax dieselolei, uma bactéria degradadora de alcanos associada ao muco do zoantídeo Palythoa caribaeorum (Cnidaria, Anthozoa)}

\begin{abstract}
Resumo
Análises dos genes $16 \mathrm{~S}$ rDNA foram empregadas para identificar a microbiota isolada do muco do zoantídeo Palythoa caribaeorum de Porto de Galinhas, litoral do estado de Pernambuco, Brasil. Este estudo é importante pelo ineditismo dessa associação, pelas relevantes aplicações biotecnológicas da bactéria Alcanivorax dieselolei e pela indicação da presença de uma bactéria degradadora de hidrocarbonetos em um ecossistema recifal como o de Porto de Galinhas.
\end{abstract}

Palvras-chave: 16S rDNA, microbiota, biodegradação, hidrocarbonetos, cnidários.

\section{Introduction}

Coral reefs are complex ecosystems that provide microniches for enormous diversities of microorganisms (Ainsworth et al., 2010) associated with marine invertebrates such as sponges, cnidarians, and mollusks (Sfanos et al., 2005). Cnidarians, especially corals, have many microorganisms associated with their tissues and mucus (Rohwer et al., 2002; Chimetto et al., 2009; Castro et al., 2010). Coral mucus - a micro-layer of polysaccharides and glycoproteins deposited over the surfaces of these animals - has been found to contain representatives of the three primary domains Archaea, Eubacteria and Eukarya (Meikle et al., 1988; Wegley et al., 2007).

While a number of workers studies have examined the microbiota associated with corals and other marine invertebrates (Castro et al., 2010; Menezes et al., 2010; Trindade-Silva et al., 2012), zoanthids have been little examined in that respect, although some investigations of the diversity of bacteria found on zoanthids by Chimetto et al.
(2008, 2009, 2011) identified 16S rDNA sequences of bacteria of the genus Vibrio.

The zoanthid Palythoa caribaeorum (Duchassaing and Michelotti, 1860) is a cnidarian commonly found on reefs in the Caribbean region and Brazil (Mueller and Haywick, 1995). It can form dense layers on reefs as it is a strong competitor for space (Pérez et al., 2005), is tolerant of environmental stresses (Sebens, 1982), demonstrates a high reproductive capacity (Acosta and Asbahr, 2000), and liberates a potent non-protein toxin called palytoxin (Seemann et al., 2009). This cnidarian is popularly known as "baba-de-boi" ("cattle spittle") as it secretes a very viscous mucus over the surface of the colony during low tides that can shelter other marine microorganisms (Ainsworth et al., 2010).

The bacterium Alcanivorax dieselolei was originally isolated from seawater samples and marine sediments contaminated by oil in the Pacific Ocean and described by Liu and Shao (2005). These bacteria, as well as other 
species of the same genus, predominate in temperate marine environments impacted by oil (Cappello et al., 2007).

The present work represents the first record of A. dieselolei, a specie capable of degrading petroleum derivatives, in the Atlantic Ocean and associated with the zoanthid $P$. caribaeorum. The potential biotechnological applications of the bacterium are discussed.

\section{Material and Methods}

Mucus was collected from exposed reef colonies of $P$. caribaeorum (Figure 1) during low tide periods in May/2010 at Porto de Galinhas on the southern coast of Pernambuco State, Brazil (8³0'24'’S; 3459'52'”W) (Figure 2). Mucus samples were scraped and placed in sterile $50 \mathrm{~mL}$ centrifuge tubes. Heterotrophic bacteria were isolated from the mucus by inoculating $2 \mathrm{~mL}$ of the collected mucus onto Marine Agar 2216 (Difco ${ }^{\circledR}$ ) using the pour plate technique and incubating the cultures at $30{ }^{\circ} \mathrm{C}$ for five days.

DNA was extracted from individual bacterial colonies using the thermal shock technique, in which a small quantity of material from each colony was collected and resuspended in $100 \mu \mathrm{l}$ of ultrapure sterilized water, exposed to temperatures of $98{ }^{\circ} \mathrm{C}$ for $10 \mathrm{~min}$. and $-20{ }^{\circ} \mathrm{C}$ for 10 min. and subsequently centrifuged; the supernatants were transferred to sterile tubes.

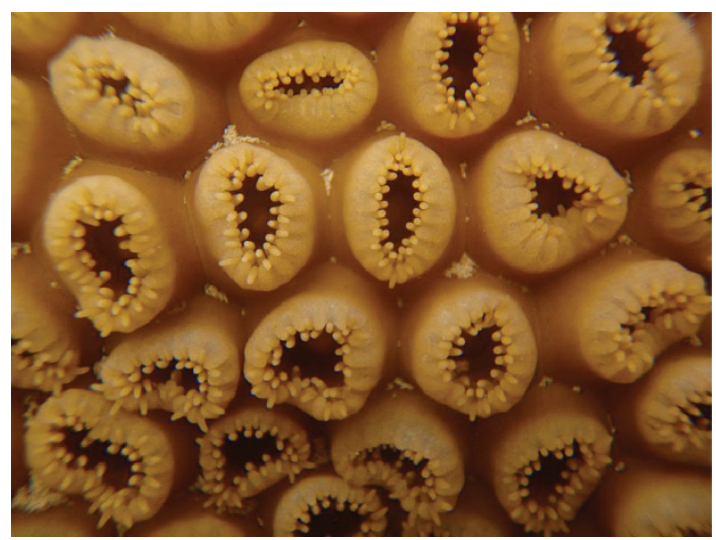

Figure 1. Colony of zoanthid Palythoa caribaeorum (Photo: Liany Melo).

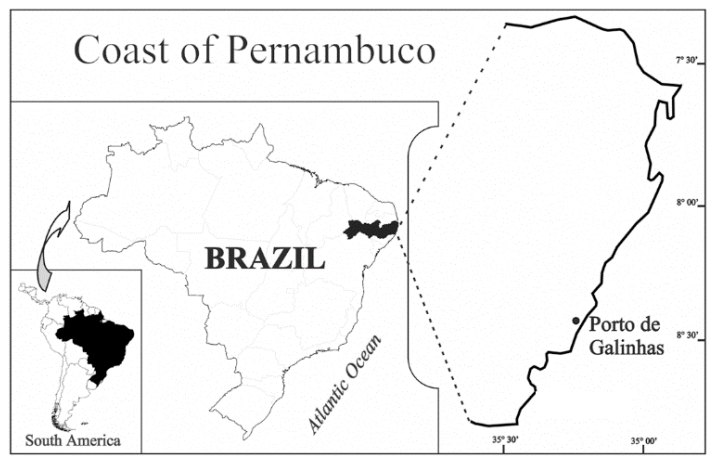

Figure 2. Map of the coast of the state of Pernambuco indicating the collection point.
The total DNA from each sample was used as a template for amplifying the 16S rDNA segments of Eubacteria using the primers $27 \mathrm{~F}$ ( 5 ' AGA GTT TGA TCM TGG CTC AG 3') and 1492R (5' TAC GCY TAC CTT GTT ACG ACT T 3') (Rohwer et al., 2002). The PCR reactions were performed in a final volume of $50 \mu \mathrm{l}$ that included: $50 \mathrm{ng}$ of the template DNA, 10 pmol of each primer, $200 \mu \mathrm{M}$ dNTPs, $5 \mu$ l PCR buffer, $5 \mathrm{U}$ of Taq polymerase for DNA $\left(\right.$ Fermentas ${ }^{\circledR}$ ), and $22 \mu$ l of ultrapure sterilized water. The thermocycler program consisted of: (1) 5 minutes at $94{ }^{\circ} \mathrm{C}$; (2) 30 cycles of 1 minute at $94^{\circ} \mathrm{C}, 1$ minute at $62^{\circ} \mathrm{C}$, and 3 minutes at $72{ }^{\circ} \mathrm{C}$, and; (3) 10 minutes at $72{ }^{\circ} \mathrm{C}$. The PCR products were purified using the QIAquick PCR Purification kit (QIAGEN $\left.{ }^{\circledR}\right)$.

The sequencing reactions were performed using BigDye ${ }^{\circledR}$ (ABI) and DYEnamic ET (Amersham Biosciences ${ }^{\circledR}$ ) chemistry for the ABI Prism (Model 3100). The reactions were performed in a final volume of $10 \mu \mathrm{l}$ containing: $100 \mathrm{ng}$ of template DNA (the amplification products), $2 \mu \mathrm{l}$ of marked nucleotides, 25X PCR buffer (20 mM Tris- $\mathrm{HCl}$ $\mathrm{pH}=8.4$ ), 25 pmoles of each primer (forward and reverse), and previously sterilized Milli-Q water (q.s.p. $20 \mu \mathrm{l}$ ). These reactions were performed using the same program described above for the PCR reactions.

The qualities of the resulting DNA sequences were evaluated using Sequencing Analysis 3.4 software (Applied Biosystems $^{\circledR}$, Foster City, CA, EUA). The sequences were submitted to nucleotide similarity consultations of the data available at GenBank, on the the NCBI (National Center for Biotechnology Information) web site using the BLASTn algorithm (Altschul et al., 1990).

\section{Results and Discussion}

Fifty bacterial isolates were obtained from the mucus of $P$. caribaeorum collected on reefs in Porto de Galinhas, Pernambuco State, Brazil. The dominant group among the isolated bacteria was $\gamma$-Proteobacteria, with 36 isolates (72\%), followed by $\alpha$-Proteobacteria and Actinobacteria with six isolates each $(12 \%)$, and Firmicutes with two isolates (4\%); one isolate of $A$. dieselole $i$ was encountered among the $\gamma$-Proteobacteria. Comparisons of the nucleotide sequence of the $16 \mathrm{~S}$ rDNA gene of the bacterium isolated from $P$. caribaeorum mucus with sequences deposited in the GenBank indicated similarities $100 \%$ with the sequences of the group that performed the complete genome sequence of $A$. dieselolei Type Strain B5 (Lai et al., 2012). The nucleotide sequence was deposited in GenBank with the accession number KF545933.

We therefore report here the first known association of the bacteria $A$. dieselole $i$ with the zoanthid P. caribaeorum. Sequences of this bacteria had only previously been obtained from seawater and marine sediment samples (Liu and Shao, 2005; Tapilatu et al., 2010), as is true for most of the other isolates and 16S rRNA gene sequences of other bacterial strains of the genus Alcanivorax (Liu and Shao, 2005; Cappello et al., 2007; Rivas et al., 2007; Wu et al., 2009). Some presently non-identified strains of the genus 
Alcanivorax have been isolated from marine invertebrates such as sponges and gorgonians (Sfanos et al., 2005), but our current report is the first record of any association between $A$. dieselolei and $P$. caribaeorum, and its first reported occurrence in the Atlantic Ocean.

Among the hydrocarbonoclastic bacteria, the genus Alcanivorax comprises Gram-negative, aerobic, and halophytic species that have the capacity to metabolize alkanes hydrocarbons as a carbon source and for energy and have been used in bioremediation projects in polluted marine environments (Yakimov et al., 1998; Liu and Shao, 2005). The genus Alcanivorax comprises six described species: Alcanivorax borkumensis (Yakimov et al., 1998), Alcanivorax venustensis, Alcanivorax jadensis (FernándezMartínez, 2003), Alcanivorax dieselolei (Liu and Shao, 2005), Alcanivorax balearicus (Rivas et al., 2007), and Alcanivorax hongdengensis (Wu et al., 2009).

The fact that $A$. dieselole $i$ was isolated from colonies of $P$. caribaeorum is quite intriguing because, while the beach at Porto de Galinhas has been heavily visited by tourists, it does not appear to be contaminated to any significant degree by petroleum compounds in spite of its proximity to the shipping port at Suape. On the other hand, large numbers of swimmers and divers do visit this beach and use solar protection lotions containing hydrocarbons such as benzophenone, oxybenzone, or parabens. These compounds may serve as energy and carbon sources for bacteria that metabolize only alkanes and reject other carbon resources such as sugars and amino acids (Lorenzo, 2006).

The presence of the bacteria A. dieselolei in P. caribaeorum mucus might also be at least partially explained by the presence of high concentrations of phosphorus and nitrogen compounds (commonly used in bioremediation projects to break bacterial dormancy) in that milieu (Cappello et al., 2007). It is also known that bacteria of the genus Vibrio, which can fix nitrogen, are associated with this same zoanthid (Chimetto et al., 2008) so that $A$. dieselolei may be using these compounds as energy sources as these bacteria show denitrification activity and Alcanivorax strains are known to contribute to the degradation of nitrogen and phosphorus compounds that accumulate in organically enriched coastal areas (Nakano et al., 2009).

Another possible explanation for the presence of this bacterium in association with $P$. caribaeorum would be the natural production of aliphatic compounds by that animal. According to Yakimov et al. (2007), the isolation of the bacteria $A$. borkumensis from marine invertebrates may reflect the existence of specific ecological niches containing hydrocarbons produced by those animals themselves. The presence of $A$. borkumensis in non-polluted environments (Kasai et al., 2001) indicates that $A$. dieselolei might likewise naturally exist in environments not polluted by oil. It will be necessary to monitor the Porto de Galinhas beach area for possible environmental impacts in any case, as these bacteria can be used as bioindicators of water contamination by either high or low levels of long-chain hydrocarbons (Fernández-Martínez et al., 2003).
Other genera (similarity indices $\geq 97 \%$ ) with bacterial species with known capabilities to degrade alkanes derived from petroleum were also found associated with the secreted mucus of $P$. caribaeorum in the present work, including Altererytrobacter, Pseudomonas, Rhodococcus, and Stappia - which is interesting from the point of view of possible biotechnological applications. The present study also represents the first report of the association of these bacteria with the zoanthid $P$. caribaeorum, a cnidarian that has been only poorly examined in terms of its associated microbiota in spite of its abundance in most reef environments in the western Atlantic.

\section{Acknowledgements}

The authors would like to thank Fundação de Amparo à Ciência e Tecnologia do Estado de Pernambuco for their financial support to research and for the Master's grant awarded to F.F.C., as well as Dra. Michelle Oliveira for her help in cultivating the bacteria in the laboratory.

\section{References}

ACOSTA, A. and ASBAHR, M., 2000. Reproductive effort in Palythoa caribaeorum. In Proceedings of the 9th International Coral Reef Symposium, 2000. Bali. Bali: ICRS. p. 295.

AINSWORTH, TD., THURBER, RV. and GATES, RD., 2010. The future of coral reefs: a microbial perspective. Trends in Ecology \& Evolution, vol. 25, no. 4, p. 233-240. http://dx.doi. org/10.1016/j.tree.2009.11.001. PMid:20006405

ALTSCHUL, SF., GISH, W., MILLER, W., MYERS, EW. and LIPMAN, DJ., 1990. Basic local alignment search tool. Journal of Molecular Biology, vol. 215, no. 3, p. 403-410. http://dx.doi. org/10.1016/S0022-2836(05)80360-2. PMid:2231712

CAPPELlO, S., DENARO, R., GENOVESE, M., GIULIANO, L. and YAKIMOV, MM., 2007. Predominant growth of Alcanivorax during experiments on "oil spill bioremediation" in mesocosms. Microbiological Research, vol. 162, no. 2, p. 185-190. http://dx.doi. org/10.1016/j.micres.2006.05.010. PMid:16831537

CASTRO, AP., ARAÚJO JUNIOR, SD., REIS, AMM., MOURA, RL., FRANCINI-FILHO, RB., PAPPAS JUNIOR, G., RODRIGUES, TB., THOMPSON, FL. and KRÜGER, RH., 2010. Bacterial community associated with healthy and diseased reef coral Mussismilia hispida from eastern Brazil. Microbial Ecology, vol. 59, no. 4, p. 658-667. http://dx.doi.org/10.1007/ s00248-010-9646-1. PMid:20352207

CHIMETTO, LA., BROCCHI, M., GONDO, M., THOMPSON, CC., GOMEZ-GIL, B. and THOMPSON, FL., 2009. Genomic diversity of vibrios associated with the Brazilian coral Mussismilia hispida and its sympatric zoanthids (Palythoa caribaeorum, Palythoa variabilis and Zoanthus solanderi). Journal of Applied Microbiology, vol. 106, no. 6, p. 1818-1826. http://dx.doi. org/10.1111/j.1365-2672.2009.04149.x. PMid:19291243

CHIMETTO, LA., BROCCHI, M., THOMPSON, CC., MARTINS, RCR., RAMOS, HR. and THOMPSON, FL., 2008. Vibrios dominate as culturable nitrogen-fixing bacteria of the Brazilian coral Mussismilia hispida. Systematic and Applied Microbiology, vol. 31, no. 4, p. 312-319. http://dx.doi.org/10.1016/j.syapm.2008.06.001. PMid:18678453 
CHIMETTO, LA., CLEENWERCK, I., ALVES JUNIOR, N., SILVA, BS., BROCCHI, M., WILLEMS, A., DE VOS, P. and THOMPSON, FL., 2011. Vibrio communis sp. nov., isolated from the marine animals Mussismilia hispida, Phyllogorgia dilatata, Palythoa caribaeorum, Palythoa variabilis and Litopenaeus vannamei. International Journal of Systematic and Evolutionary Microbiology, vol. 61, no. 2, p. 362-368. http://dx.doi.org/10.1099/ ijs.0.019729-0. PMid:20305064

FERNÁNDEZ-MARTÍNEZ, J., PUJALTE, MJ., GARCÍAMARTÍNEZ, J., MATA, M., GARAY, E. and RODRÍGUEZVALERAL, F., 2003. Description of Alcanivorax venustensis sp. nov. and reclassification of Fundibacter jadensis DSM 121 78T (Bruns and Berthe-Corti 1999) as Alcanivorax jadensis comb. nov., members of the emended genus Alcanivorax. International Journal of Systematic and Evolutionary Microbiology, vol. 53, no. 1, p. 331-338. http://dx.doi.org/10.1099/ijs.0.01923-0. PMid: 12656192

KASAI, Y., KISHIRA, H., SYUTSUBO, K. and HARAYAMA, S., 2001. Molecular detection of marine bacterial populations on beaches contaminated by the Nakhodka tanker oil-spill accident. Environmental Microbiology, vol. 3, no. 4, p. 246-255. http:// dx.doi.org/10.1046/j.1462-2920.2001.00185.x. PMid:11359510

LAI, Q., LI, W. and SHAO, Z., 2012. Complete genome sequence of Alcanivorax dieselolei type strain B5. Journal of Bacteriology, vol. 194, no. 23, p. 6674. http://dx.doi.org/10.1128/JB.01813-12. PMid:23144414

LIU, C. and SHAO, Z., 2005. Alcanivorax dieselolei sp. nov., a novel alkane-degrading bacterium isolated from sea water and deep-sea sediment. International Journal of Systematic and Evolutionary Microbiology, vol. 55, no. Pt 3, p. 1181-1186. http:// dx.doi.org/10.1099/ijs.0.63443-0. PMid:15879252

LORENZO, V., 2006. Blueprint of an oil-eating bacterium. Nature Biotechnology, vol. 24, no. 8, p. 952-953. http://dx.doi. org/10.1038/nbt0806-952. PMid:16900140

MEIKLE, P., RICHARDS, GN. and YELLOWLEES, D., 1988. Structural investigations on the mucus from six species of coral. Marine Biology, vol. 99, no. 2, p. 187-193. http://dx.doi. org/10.1007/BF00391980.

MENEZES, CBA., BONUGLI-SANTOS, RC., MIQUELETTO, PB., PASSARINI, MRZ., SILVA, CHD., JUSTO, MR., LEAL, RR., FANTINATTI-GARBOGGINI, F., OLIVEIRA, VM., BERLINCK, RGS. and SETTE, LD., 2010. Microbial diversity associated with algae, ascidians and sponges from the north coast of São Paulo state, Brazil. Microbiological Research, vol. 165, no. 6, p. 466-482. http://dx.doi.org/10.1016/j.micres.2009.09.005. PMid:19879115

MUELLER, E. and HAYWICK, DW., 1995. Sediment assimilation and calcification by the Western Atlantic reef zoanthid, Palythoa caribaeorum. Bulletin de l'Institut Oceanographique, vol. 14, p. $89-100$.

NAKANO, M., OKUNISHI, S., TANAKA, R. and MAEDA, H., 2009. Denitrifying activity and homologous enzyme analysis of Alcanivorax dieselolei strain N1203. Biocontrol Science, vol. 14, no. 3, p. 97-105. http://dx.doi.org/10.4265/bio.14.97. PMid:19785282

PÉREZ, CD., VILA-NOVA, DA. and SANTOS, AM., 2005. Associated community with the zoanthid Palythoa caribaeorum (Duchassaing \& Michelotti, 1860) (Cnidaria, Anthozoa) from littoral of Pernambuco, Brazil. Hydrobiologia, vol. 548, no. 1, p. 207-215. http://dx.doi.org/10.1007/s10750-005-5441-2.
RIVAS, R., GARCÍA-FRAILE, P., PEIX, A., MATEOS, PF., MARTÍNEZ-MOLINA, E. and VELÁZQUEZ, E., 2007. Alcanivorax balearicus sp. nov., isolated from Lake Martel. International Journal of Systematic and Evolutionary Microbiology, vol. 57, no. 6, p. 1331-1335. http://dx.doi.org/10.1099/ijs.0.64912-0. PMid:17551053

ROHWER, F., SEGURITAN, V., AZAM, F. and KNOWLTON, N., 2002. Diversity and distribution of coral associated bacteria. Marine Ecology Progress Series, vol. 243, p. 1-10. http://dx.doi. org/10.3354/meps243001

SEBENS, KP, 1982. Intertidal distribution of zoanthids on the Caribbean coast of Panama: effects of predation and dessication. Bulletin of Marine Science, vol. 32, p. 316-335.

SEEMANN, P., GERNERT, C., SCHMITT, S., MEBS, D. and HENTSCHEL, U., 2009. Detection of hemolytic bacteria from Palythoa caribaeorum (Cnidaria, Zoantharia) using a novel palytoxin-screening assay. Antonie Leeuwenhoek International Journal of Micobiology, vol. 96, no. 4, p. 405-411. http://dx.doi. org/10.1007/s10482-009-9353-4.

SFANOS, K., HARMODY, D., DANG, P., LEDGER, A., POMPONI, S., MCCARTHY, P. and LOPEZ, J., 2005. A molecular systematic survey of cultured microbial associates of deep-water marine invertebrates. Systematic and Applied Microbiology, vol. 28, no. 3, p. 242-264. http://dx.doi.org/10.1016/j.syapm.2004.12.002. PMid:15900971

TAPILATU, Y., ACQUAVIVA, M., GUIGUE, C., MIRALLES, G., BERTRAND, JC. and CUNY, P., 2010. Isolation of alkanedegrading bacteria from deep-sea Mediterranean sediments. Letters in Applied Microbiology, vol. 50, no. 2, p. 234-236. http:// dx.doi.org/10.1111/j.1472-765X.2009.02766.x. PMid:19943883

TRINDADE-SILVA, AE., RUA, C., SILVA, GGZ., DUTILH, BE., MOREIRA, APB., EDWARDS, RA., HAJDU, E., LOBOHAJDU, G., VASCONCELOS, AT., BERLINCK, RGS. and THOMPSON, FL., 2012. Taxonomic and functional microbial signatures of the endemic marine sponge Arenosclera brasiliensis. PLOS ONE, vol. 7, no. 7, p. e39905. http://dx.doi.org/10.1371/ journal.pone.0039905. PMid:22768320

WEGLEY, L., EDWARDS, R., RODRIGUEZ-BRITO, B., LIU, H. and ROHWER, F., 2007. Metagenomic analysis of the microbial community associated with the coral Porites astreoides. Environmental Microbiology, vol. 9, no. 11, p. 2707-2719. http:// dx.doi.org/10.1111/j.1462-2920.2007.01383.x. PMid:17922755

WU, Y., LAI, Q., ZHOU, Z., QIAO, N., LIU, C. and SHAO, Z., 2009. Alcanivorax hongdengensis sp. nov., an alkane-degrading bacterium isolated from surface seawater of the straits of Malacca and Singapore, producing a lipopeptide as its biosurfactant. International Journal of Systematic and Evolutionary Microbiology, vol. 59, no. 6, p. 1474-1479. http://dx.doi.org/10.1099/ijs.0.0015520. PMid: 19502338

YAKIMOV, MM., GOLYSHIN, PN., LANG, S., MOORE, ERB., ABRAHAM, WR., LÜNSDORF, H. and TIMMIS, KN., 1998. Alcanivorax borkumensis gen. nov., sp. nov., a new hydrocarbondegrading and surfactant-producing marine bacterium. International Journal of Systematic Bacteriology, vol. 48, no. 2, p. 339-348. http://dx.doi.org/10.1099/00207713-48-2-339.</jrn>.

YAKIMOV, MM., TIMMIS, KN. and GOLYSHIN, PN., 2007. Obligate oil-degrading marine bacteria. Current Opinion in Biotechnology, vol. 18, no. 3, p. 257-266. http://dx.doi.org/10.1016/j. copbio.2007.04.006. PMid:17493798 